\title{
La crónica de Juan de Paiva sobre el juego de pelota en Apalache/
}

\section{Juan de Paiva's Chronicle on the Apalachee Ball Game}

\author{
David Arbesú \\ ORCID iD: http://orcid.org/0000-0002-5582-271X \\ University of South Florida
}

El presente artículo busca dar a conocer un texto escrito en 1676 por el padre Juan de Paiva sobre los orígenes mitológicos del juego de pelota de los indios de Apalache y las ceremonias asociadas al mismo. El manuscrito, conservado en el Archivo General de Indias, está inédito, y tiene la particularidad de ser una de las dos únicas fuentes documentales que arrojan datos sobre la lengua y cultura de los indios de Apalache en el sistema de misiones españolas de La Florida. Un correcto establecimiento del texto nos permitirá, además, adentrarnos en el significado ritual de las ceremonias y orígenes del juego de pelota.

Palabras Clave: Juan de Paiva; Florida; Apalache; Juego de Pelota; Mitología.

The purpose of this article is to publish the 1676 narrative of father Juan de Paiva concerning the mythological origins of the Apalachee ball game and its ceremonial practices. The manuscript, housed at the Archivo General de Indias, has never been edited in Spanish, despite being one of the two extant sources that shed light on the language and culture of the Apalachee Indians within the Spanish mission system of $17^{\text {th }}$-century Florida. A correct interpretation of the text, I contend, allows for a more accurate reading of the symbolism behind the ceremonies and mythic origins of the game.

Keywords: Juan de Paiva; Florida; Apalachee; Ball Game; Mythology.

Copyright: (C) 2017 CSIC. Este es un artículo de acceso abierto distribuido bajo los términos de una licencia de uso y distribución Creative Commons Attribution (CC-by) España 3.0. 
En el Archivo General de Indias de Sevilla se conserva un breve tratado titulado Origen y prinsipio del juego de pelota que los indios apalachinos y ustacanos han estado jugando desde su infidelidad hasta el año de $1676 .{ }^{1}$ Escrito por el padre Juan de Paiva en la misión de San Luis de Talimali, el manuscrito es una rareza documental, puesto que, por lo general, los datos relativos a la cultura tradicional de los nativos del sudeste norteamericano suelen limitarse a menciones breves y esporádicas que no arrojan apenas datos de valor. En este caso, no obstante, el documento es tan excepcional que cuando Geoffrey Kimball se propuso redactar un diccionario de apalache a principios de la década de 1980, los únicos testimonios en los que pudo apoyarse fueron este manuscrito y «una carta dirigida al rey Carlos II en 1688 que está hoy en paradero desconocido». ${ }^{2}$ Además, su descripción de los ritos, ceremonias y orígenes mitológicos del juego de pelota es tan detallada que «casi todo lo que conocemos directamente sobre las creencias religiosas de los indios de Apalache deriva de este manuscrito», ${ }^{3} \mathrm{y}$ sin embargo no existe ni un solo estudio fuera de los círculos académicos norteamericanos que le preste atención, no contamos con ninguna edición del texto en español y únicamente se ha publicado una traducción al inglés que debería revisarse. ${ }^{4}$

El documento que se conserva hoy no es el original de Paiva, sino la copia realizada por el capitán Juan Hernández de Florencia el 28 de mayo de 1677 con la intención de enviársela a su hermano Francisco, un jesuita estacionado en Nueva España. Así se desprende de la carta firmada por el capitán en el primero de los folios, cuya letra coincide exactamente con la del resto del manuscrito. Sin embargo, sabemos que el tratado sobre el juego de pelota fue compuesto el 23 de septiembre de 1676 por «el santo padre reverendo Juan de Paiva ${ }^{5} \mathrm{y}$, de manera más importante, que mucha de la información que aparece en el cuaderno está tomada directamente de la tradición oral de los indios de Apalache. En efecto, para recopilar los mitos

1 Archivo General de Indias (AGI), Escribanía de Cámara, 156A, ff. 568r-583v.

2 Kimball, 1987, 136; Kimball, 1988, 387. En lo sucesivo, todas las traducciones son mías.

3 Hann y McEwan, 1998, 12.

4 La única traducción publicada es la de Hann (1988, 328-353), aunque existe transcripción del original de J. T. Connor (Library of Congress, 1) y sendas traducciones de Julian Granberry (National Anthropological Archives, Papers of W. C. Sturtevant, 131) y Evelyn Peterson (Florida Bureau of Archaeological Research). No es este el lugar para discutir los numerosos pasajes problemáticos de la traducción de Hann. Me conformo con apuntar que el mismo autor admite que este manuscrito fue «el primer documento español del siglo XVII con el que tuve el placer de lidiar». Hann, 1988, 329.

5 AGI, Escribanía de Cámara, 156A, f. 569r. Lo poco que sabemos sobre el padre Paiva viene recogido con detalle en Hann, 1991, 140-167. 
y ceremonias del juego de pelota Paiva alistó la ayuda de dos nativos, Diego Salvador y Juan Mendoza, ambos «ejemplos notables de la hispanización de los indígenas». ${ }^{6}$ Salvador era sargento mayor en la milicia y hacía las veces de intérprete real, mientras que Mendoza era el cacique de San Luis de Talimali e intérprete de la iglesia. El propio Paiva admite que fueron ellos quienes interrogaron a otros indios de la región, con lo que el texto conservado es un verdadero palimpsesto de niveles narrativos. No es de extrañar, pues, que algunos críticos hayan reconocido en el documento trazos del «estilo típico de la tradición oral de gran parte de la literatura de los indígenas norteamericanos», incluso cuando hay que tener en cuenta que entre el original y la copia conservada hubo al menos dos códices interpuestos. ${ }^{7}$

El afán por prohibir el juego de pelota, uno de los juegos más populares entre los nativos de Norteamérica ${ }^{8}$ era algo nuevo para Paiva. En los catorce años que llevaba residiendo en Florida, el ahora guardián de San Luis de Talimali había tolerado alegremente la práctica, e incluso fue él quien salió en su defensa cuando el obispo de Cuba, Gabriel Díaz Vara Calderón, prohibió el juego en 1675. ${ }^{9}$ Gracias a la mediación de Paiva el obispo revocó su decisión, pero, tras la visita pastoral, el religioso comenzó a observar el juego más detenidamente y llegó a la conclusión de que este era un deporte violento y pernicioso que a menudo concluía con un sinfín de jugadores «cojos, pierniquebrados, mancos, tuertos [y] liçiados», además de varios muertos. ${ }^{10}$ Unos meses más tarde, en el verano de 1676, un grupo de guerreros de la vecina tribu Chisca entró en Apalache y saqueó el pueblo de Ivitachuco, que se encontraba totalmente desamparado a causa

6 Bushnell, 1978, 10.

7 Shields $(2000,227)$ y Hann y McEwan $(1998,125)$ hacen referencia a la tradición oral. Los niveles narrativos a los que me refiero son (a) tradición oral, (b) cuaderno de Salvador y Mendoza, (c) cuaderno de Paiva, (d) copia de Hernández de Florencia que se conserva en AGI con los papeles de la visita de Domingo de Leturiondo. Los códices interpuestos son, obviamente, (b) y (c). En el último folio, y en varias manos diferentes, aparecen las firmas de Salvador y Mendoza, así como la ratificación del capitán Martín Lorenzo de Labora, quien hizo las veces de escribano durante la visita de Leturiondo, certificando —el 26 de diciembre de 1677-que los intérpretes «reconosieron y vieron este cuaderno que dixeron ser el mesmo que contenía los atresos y super[s]ticiones del juego de pelota que la nación abalachina había estado jugando». AGI, Escribanía de Cámara, 156A, f. 583r.

8 No entro aquí en una descripción del juego de pelota — que puede leerse más adelante en la misma crónica que editamos - y remito en general al estudio clásico de Culin (1992 [1907], 561-612), y más específicamente para la región de Apalache a Hann (1988, 73-75 et passim) y Hann y McEwan (1998, 14-18).

9 Hann, 1991, 150. La visita del obispo a Florida duró aproximadamente diez meses, desde el 23 de agosto de 1674 al 21 de junio de 1675 . Wenhold, 1936, 8.

10 AGI, Escribanía de Cámara, 156A, f. 580v. 
de un juego de pelota. ${ }^{11}$ Paiva sintió remordimientos por haber convencido a Calderón de revocar su prohibición y se responsabilizó de la catástrofe que estuvo a punto de costarle la provincia a la corona española, aprestándose a denunciar un juego que ahora consideraba un «tributo al demonio». ${ }^{12}$

Las razones esbozadas por Paiva para abolir el juego de pelota no son exclusivas de la región del sudeste norteamericano, ya que desde mediados del siglo XVI los cronistas de Indias habían comenzado a advertir «de los peligros de robo y altercados que solían ocurrir merced al tumulto formado por los muchos asistentes a tales eventos». ${ }^{13}$ Sin embargo, la parte que da título al tratado, el «origen y principio del juego de pelota», sí que es exclusiva de Paiva, ya que ningún otro autor en las Américas ha sido nunca capaz de recopilar con tanto detalle las tradiciones y rituales de un determinado pueblo en lo relativo a su particular variedad del juego de pelota. ${ }^{14}$ Además de contener dos secciones referentes a los «abusos y agüeros y superstiçiones» para levantar el poste y jugar a «este endemoniado juego», ${ }^{15}$ el manuscrito contiene un sugestivo relato sobre los orígenes de dicha práctica en el que Paiva encontró razones más que suficientes para abolirla. Así, en los primeros folios del tratado se relata la historia del joven Eslafiayupi, bisnieto de Itonanslak (dios de las hogueras) e hijo de Niko Tayholo (esposa del sol), quien estaba llamado, según una profecía, a matar al dios del trueno Ocona Niko Watka para ocupar su lugar en el panteón de los dioses. ${ }^{16}$

Si bien pudiera parecer que a un nivel superficial la historia refleja únicamente un enfrentamiento entre dos viejos espíritus o dioses de Apalache, Gregory Keyes ha argumentado, con razón, que «pronto se hace evidente que el relato es algo más que una historia entretenida». ${ }^{17}$ En efecto, un análisis más detallado del texto revela que la historia se atiene, por

11 Bushnell, 1978, 8.

12 AGI, Escribanía de Cámara, 156A, f. 568r.

13 Perea Rodríguez, 2015, IX, 56.

14 Por citar un solo ejemplo, en la Crónica de la Nueva España se relata la afición de Moctezuma por el juego de pelota «que ahora les es prohibido a los indios por el mucho riesgo que en él se corre», pero la descripción de las ceremonias asociadas al juego es muy somera, afirmando únicamente que el jugador que anotaba un tanto «era obligado a hacer ciertos sacrificios al ídolo del trinquete y piedra por cuyo agujero metió la pelota [y que] a la medianoche de un día de buen signo, con ciertas cerimonias y hechicerías, y en medio del suelo hacían otras tales, cantando romances y canciones que para ello tenían; luego venía un sacerdote del templo mayor con ciertos religiosos a lo bendecir». Cervantes de Salazar, 1971, I, 314-315.

15 AGI, Escribanía de Cámara, 156A, ff. 575r y 576r.

16 Debido a que la ortografía de los nombres varía en el manuscrito, en la introducción y notas utilizo la ortografía propuesta por Kimball en su diccionario de apalache. Kimball, 1987 y 1988.

17 Keyes, 1994, 108. 
una parte, a concepciones generales del monomito universal esbozado por Raglan (como ser hijo de una divinidad o tener que superar tres pruebas para vencer a un enemigo) y, por otra, a elementos muy particulares de la cultura de Apalache. ${ }^{18}$ La misteriosa concepción del héroe (su madre se queda embarazada mientras va a por agua), los tres cambios de nombre del muchacho (Chita, Oklafi, Eslafiayupi), el tipo de pruebas que debe superar para vencer a Ocona Niko Watka y, finalmente, el relato de la creación del juego de pelota, reflejan la cosmogonía dualista de los indios de Apalache y delatan la conexión de esta leyenda con otros mitos de los grupos indígenas de Norteamérica. Entretejidos en el mito de Eslafiayupi y el juego de pelota se vislumbran aun prácticas culturales de los nativos, como por ejemplo ciertas referencias alegóricas a festividades (ceremonia del maíz, ritos de fertilidad), alusiones a su sistema político y social (sociedad matrilineal, división de clanes en «rojos» y «blancos»), prácticas religiosas luego extinguidas (división del mundo en tres niveles, dioses-animales, conexión de las élites con el sol) y varios elementos que evidencian el sincretismo religioso surgido de la conquista española. ${ }^{19}$

Esta ingente cantidad de referencias culturales, así como el hecho de que el manuscrito es resultado de sobreponer el contenido de otros dos o tres testimonios, es lo que ha ocasionado, en mi opinión, que hasta el momento no contemos con una edición del mismo. Amy Bushnell no dudó en describirlo como «la pesadilla de un traductor, lleno de saltos en el tiempo, digresiones, erratas, y con una sintaxis distorsionada y pronombres sin referentes, además de sus pinceladas de apalache, timucua y latín». ${ }^{20} \mathrm{Sin}$ compartir enteramente su opinión, es cierto que el cuaderno de Paiva (o, mejor, la copia de Hernández de Florencia) es de difícil interpretación, y sin embargo es esta misma dificultad la que hace imprescindible una correcta fijación del texto. Todas las partes del manuscrito, desde el mito fundacional del juego de pelota hasta la obsesión de Paiva por demonizarlo, pasando por

18 Para el monomito puede consultarse Raglan, 2003, 174.

19 No entro aquí en el análisis de estos elementos, que, por su complejidad, debe ser objeto de un estudio aparte. Para una descripción detallada de los apalache remito a McEwan (2004) y Hann (1992), sobre todo en lo referente a su organización política. Para las sociedades indígenas matrilineales en Norteamérica pueden consultarse Hann, 1988, 70; Hann y McEwan, 1998, 15; Lankford, 2008, 88-89; o Scarry, 2010, 29-30. Para las alusiones a dioses-animales véase Lankford, 2008, 110. Para la división alegórica entre pueblos «rojos» y «blancos» y para otros mitos de Norteamérica es imprescindible también Lankford, 2008, 73-96 et passim. La conexión entre mitología y élites se detalla en Scarry, 2010, y Keyes, 1994, y la conexión de estos mitos con la importante ceremonia del maíz viene explicada en Weisman, 1989, 157-161.

20 Bushnell, 1978, 14. 
las ceremonias asociadas al emplazamiento de los postes, forman un todo cohesionado que únicamente se hace visible tras una correcta interpretación del contenido. Si por ejemplo interpretamos (con John Hann) que Niko Tayholo es una «mujer del sol», ${ }^{21}$ no solo estamos despojando al héroe de su ascendencia divina (Niko = sol, Eslafiayupi es el hijo del sol), sino que, además, dificultamos la labor de interpretar otras referencias esenciales en la mitología del juego de pelota. Si al hijo principal del cacique, que ocupa el lugar de honor en las ceremonias para erigir el poste, se le conoce como el usinjulo $\left(o s i=\right.$ hijo, inholo $=$ amado) ${ }^{22}$ se deduce entonces que $\ll n i k o$ ta-i(n)holo» es la «esposa amada del sol». De la misma manera, si leemos (de nuevo con Hann) que el poste para el juego de pelota está decorado con varios «ataris», deshacemos por completo la simbología que se esconde detrás del elemento más importante de la historia, que es precisamente el que permite que todas sus partes estén estrechamente conectadas.

En efecto, al finalizar el mito de Eslafiayupi el manuscrito incluye un bosquejo del poste para el juego de pelota que reúne en sí todos los elementos de la historia. ${ }^{23} \mathrm{El}$ poste no solo conecta el mito de orígenes con la práctica del juego en sí, sino que, además, para Paiva el poste era, literalmente, «idolatría, era su ídolo [y] primero perderé la vida que tal consienta». ${ }^{24}$ Así, sabemos que el poste debía tener una orientación geográfica específica, que varios guerreros y mujeres habían de bailar a su alrededor y que el hijo del cacique tenía que ejecutar ciertas ceremonias en su honor. Además, sabemos que varios elementos responden directamente al mito de orígenes, ya que el poste se erigía «ad honorem de Nicoguadca», en su base había que enterrar «una cabellera de persona muerta en memoria de Itonanslac, su fundador»y, en el momento de izarlo, una mujer realizaba ciertas ceremonias «en memoria de Nico Taijulo, la madre de Nicoguadca». ${ }^{25}$ Sin embargo, la conexión con el mito de orígenes queda también representada perfectamente en el mismo bosquejo, ya que aquí se representan las tres pruebas enfrentadas por Eslafiayupi. Para la primera prueba, Ocona Niko

21 Hann, 1988, 331. Teniendo en cuenta la separación en el tiempo y el espacio, nos parece interesante notar que en el imperio inca las mujeres consagradas al servicio del dios Sol eran consideradas «vírgenes del sol». Mason, 1957, 181. A las concubinas de los hechiceros se las conocía en Timucua como «hijas del sol». Ehrman, 1940, 189.

22 Kimball, 1988, 393 y 395. Hann, 1992, 206-207.

23 Por su relevancia, el bosquejo se incluye más adelante (f. 574r), en el lugar que ocupa en el manuscrito.

24 AGI, Escribanía de Cámara, 156A, f. 575v.

25 Ibidem, ff. $574 \mathrm{v}-575 \mathrm{r}$. 
Watka le ordenó que acudiese a un hoyo y recogiera pedernales para puntas de flecha. Como el hoyo era profundo y peligroso, su bisabuelo le aconsejó que recogiera unas cuentas de caracol y se las diera a un pajarillo que, de esta manera, recogería los pedernales por él. En la segunda prueba Eslafiayupi debe recoger cañas de un cañaveral lleno de víboras. Su bisabuelo le aconseja entonces que tome unas parras y fabrique unos aros que podrá arrojar para que las víboras los sigan. Por último, en la tercera prueba el héroe debe encontrar un nido de águilas, matar a los padres y traer de vuelta a las crías. De nuevo es Itonanslak quien le ayuda a superar la prueba, aconsejándole que se fabrique un casco (de una calabaza) y lleve un garrote para matar a los animales.

Como se puede ver más adelante (f. 574r), el mismo poste evoca las tres pruebas de Eslafiayupi en cuanto toma la forma de una flecha. En mi opinión, aunque en la tercera no se especifique, es obvio que las tres pruebas están relacionadas con la fabricación de esta arma (punta, tallo, plumas). Además, en la parte superior del poste encontramos una estructura triangular coronada por un «nido» cubierto de «caracoles» sobre los que se asienta un «águila», elementos que evocan la primera y tercera de las pruebas. Pero, ¿qué hay de la segunda? Más allá de que el texto explica que el poste debe ser izado con parrones «por la memoria de los que llevó [Eslafiayupi] cuando fue por las flechas, de que hiso las ruedas con que engañó las víboras», ${ }^{26}$ según la lectura de Hann la segunda de las pruebas no estaría representada en el dibujo. Sin embargo, si leemos correctamente el manuscrito veremos que este no es el caso. Como ya hemos comentado, para Hann los cinco palos de sasafrás que aparecen a cada lado del poste vendrían identificados con la palabra «atari», que él asocia además a una posible «derivación obsoleta del verbo "atar"». ${ }^{27}$ Bonnie McEwan lee el término como «atasis», afirmando que está relacionado con la palabra «atássa», que denota el cuchillo o bastón utilizado en la guerra por los indios creek. ${ }^{28}$ Esta interpretación es correcta, pero con un matiz importante. En realidad el término no hace referencia al bastón (aunque la forma de los palos sí se le asemeja), sino que se refiere a la vecina tribu de Atasis, cuyos miembros eran, según los estudios etnográficos de Thomas Owen, «de la familia o tribu de la serpiente». ${ }^{29}$ En este sentido, en la iconografía

26 Ibidem, f. 574v.

27 Hann, 1988, 79.

28 McEwan, 2004, XIV, 673.

29 Owen, 1921, 64. El nombre de la tribu, es cierto, deriva de la palabra «atássa». 
de Apalache el término «atasis» denota a la serpiente, completando así la representación de las tres pruebas enfrentadas por Eslafiayupi: caracoles, serpiente y águila.

En definitiva, si bien es cierto que «debido a la falta de información detallada el significado completo del juego de pelota en el sudeste probablemente no se conozca nunca», ${ }^{30}$ es de esperar que una correcta fijación de los contenidos del cuaderno de Paiva permita, a partir de ahora, adentrarse aun más en un mundo tan desconocido y fascinante como el de la mitología de Apalache tal y como quedó recogido por los misioneros de la Florida española. Sin más, ofrecemos a continuación la transcripción del manuscrito, que sigue fielmente el texto original con la excepción de los criterios de presentación gráfica adoptados para facilitar su lectura. ${ }^{31}$

\section{TRANSCRIPCIÓN DE LA CRÓNICA DE JUAN DE PAIVA}

Archivo General de Indias, Escribanía de Cámara, 156A, ff. 568r-583v.

[568r] Muy reverendo padre mayor Francisco de Florenzia:

Pongo en manos de Vuestra Paternidad ese juego de pelota que tan bárbaramente han estado jugando los indios apalachinos hasta que Dios Nuestro Señor fue servido que salieran de la seguedad en que el demonio los tenía, de que doy a Dios Nuestro Señor infinitas graçias, pues me tomó por prensipal instrumento para haçerlo derribar y destruir y que se le acabase semejante tributo al demonio, que no seso de darle a Su Divina Majestad las graçias, reconosido de las mersedes que me ha hecho, pues por mi mano se diese prinçipio a su destruiçión, cuando pareçía ser impoçible el poderse destruir ni quitar. Semejante juego metía horror y metía espanto, prometiéndonos ruinas [y] levantamientos a lo del santo San Francisco Xavier cuando convertía los

30 Lankford, 2008, 86.

31 El uso de mayúsculas, minúsculas, acentuación y puntuación, así como la «separación y unión de palabras» siguen criterios ortográficos actuales. Se añade $h$ cuando es necesaria en las palabras castellanas y apalache. Se regulariza $g>g u$ para la oclusiva velar sonora ante «e», «i»; regularizamos asimismo $q u>c u, n b>n v, n b>m b$ y $n p>m p$, y todas las grafías que carecen de valor denotativo diferencial $(j / g r / r r, u / v / b, i / j, h / 0)$. Desaparecen las geminadas ociosas, se desarrollan todas las abreviaturas silenciosamente y se deshacen las contracciones por fonética sintáctica. Además, se indica todo añadido al texto entre corchetes. En las notas a pie de página se indica la lectura del manuscrito en aquellos casos en los que ha sido necesario corregir el texto a una posible lección de autor. En las notas a pie mantenemos la transcripción semipaleográfica sin regularizar, empleando únicamente el símbolo $<>$ para resolver abreviaturas y $\left({ }^{\wedge}\right)$ para las supresiones del propio amanuense. Por último, se han utilizado las notas para explicar conceptos o expresiones en desuso que pudieran llevar a confusión. 
japones, prometiéndoles sus bonsos desdichas y calamidades. ${ }^{32}$ Sea Dios bendito, el [juego de pelota] se quitó con todo amor, con toda suavidad, sin haber discordia ni contradiçión ninguna. Y como reconosco cuán seloso es Vuestra Paternidad del serviçio de Dios Nuestro Señor y bien de las almas, se lo dedico para que lo patroçinie con Su Divina Majestad en sus oraçiones, pidiéndole a ésos les conserve en Su Divina Graçia y a mí me la dé para servirle, pues al fin es Vuestra Paternidad fruto de esta flor, aunque es ida por sus muchos trabajos y regalos con que Su Divina Majestad nos ha querido regalar, quien a Vuestra Paternidad guarde feliçidades, como puede y yo deseo. S[an] Luis [de Talimali], y mayo 28 de 1677 años.

Beso la mano de Vuestra Paternidad muy reverenda, su hermano Juan Hernández de Florenzia.

$[569 r]^{33}$ Origen y prinsipio del juego de pelota que los indios apalachinos y ustacanos han estado jugando desde su infidelidad hasta el año de 1676. Sacó a luz el santo padre reverendo Juan de Paiva, padre de la doctrina de San Luis de Talimali. Sea para honra y gloria de Dios. Amén.

Hubo en la infidelidad de esta naçión apalachina — que voy diçiendo su sentir de ellos con su seguedad- dos caçiques que vivían juntos o sircunvecinos el uno del otro. El uno se llamaba Ochuna Nicoguadca, que diçen es «relámpago», y el otro Itonaslaque, «persona vieja de candelas». Y entrambos en su sentir nombres de demonios, que por tales los han tenido, mayormente a el Itonanslaque. Tuvo este tal una nieta güérfana llamada Nico Taijulo, «mujer del sol». A ésta enviaban los prensipales, que son los que mandan el lugar (como, digamos, los regidores), todos los días por agua, en cuyo egerçisio se empreñó y parió un hijo. Y lo escondió entre unas matas, donde dieron con él el león, el oso y la graja. Y se lo llevaron a Itonanslac, su bisagüelo, y le dijeron cómo su nieta Nico Taijulo había parido aquel niño. Él entonses les mandó no lo dijeran a nadie, no lo contasen que [569v] su nieta había parido. Púsole por nombre Chita (no saben qué significa ni lo he podido descubrir). Criose hasta los dose años con este nombre, y mudóselo y púsole otro que fue Oclafi, «varón de agua» (éste es su modo de hablar), con cuyo nombre se crio

32 Compárense las dos alusiones a labor evangelizadora de Francisco Javier (1506-1552) en el Japón que se realizan en el manuscrito (ff. 568r y 582r) con las palabras de sus biógrafos: «Dijeron estos bonzos al señor de la tierra, que es un duque de muchas tierras, que si él consintiese que sus vasallos tomasen la ley de Dios, que se perdería la tierra y quedarían sus pagodas destruidas y desacatadas de la gente. [Los bonzos decían] que se guardasen de tomar la ley que predicábamos, porque la hora que fuese nuestro Dios adorado en Japón, que Japón estaba perdido». Zubillaga, 1979, 388 y 397. Véase también Schurhammer, 1982, IV, 124-133 (especialmente 124 y 125 n. 7) y la Vida y milagros de San Francisco Xavier, donde la descripción también coincide: «[los bonzos] amenaçaban guerras, incendios y muertes al rey y al reino, fingiendo revelaciones». García, 1672, 251.

33 El f. 568v está en blanco. 
hasta veinte años. Y se lo quitó e le puso otro que fue Eslafiayupi (tampoco saben qué significa, diçen lo inoran), el cual mansebo sobresalía a todos en lo brioso y en lo diestro de arco y flecha, y del juego del quiçio que todas estas naçiones juegan, que es con dos varas largas (como de tres varas de medir) y una piedra chata y redonda. ${ }^{34}$

Tenía sospechas Ochuna Nicoguadca si aquel mansebo era hijo de [Nico] Taijulo, porque le habían dicho (o pronosticado, a nuestro modo) sus maestros que el hijo que pariese Nico Taijulo lo había de matar. Y por si acaso lo fuera, trató él de ver si lo podía matar y le armó los tres lasos siguientes para que en alguno peresiese. Adviértase que le había mandado el Itonanslac a su bisnieto que de todo lo que le mandasen o suçediese le diese él, primero que lo executase, cuenta, que le importaba.

$\mathrm{Y}$ así fue mandádole lo primero que fuese a tal parte donde estaba un grande hoyo de agua y muy profundo, que de allí sacase pedernales para puntas de las flechas, y que no fuesen de otra parte. Fue el mansebo luego y diole parte a su bisagüelo de lo que le manda- [570r] -ban. Y díjole:

— «Hijo, ese hoyo es muy profundo. Tú, sin riesgo de la vida, no puedes sacar los pedernales de él».

Diole unas cuentas de caracol y díjole: los pedernales».

— «Dale estas cuentas a un pajarillo que anda allí sambulliendo y pídele

Y así fue, diole las cuentas y pidióselos. Y él se los dio y los trajo a Ochuna Nicoguadca.

Mandole por segundo que fuese a tal monte donde hallaría un cañaveral de cañas, y que de allí cortase cañas y las trajese para flechas. Fue el mansebo y díjoselo a su bisagüelo lo que le mandaban. Díjole el viejo:

— «Hijo, en ese cañaveral hay muchas víboras ponsoñosas y corres mucho peligro. Lo que puedes haser es unas ruedas de parrones, y llévalas. Y, en viniendo la víbora, tira la rueda, que vaya rodando. Ella entonses irá tras la rueda, y tú ve de carrera y corta las cañas».

Conque así lo hiso. Fue, cortó sus cañas y se las trajo.

Por tersero le mandó (y por último) que fuese a tal parte donde en un árbol hallaría un nido de águilas, que fuese y matase los padres y trajera los hijos. El mansebo fue y dio parte al viejo, y él le dio el consejo que se sigue. Y fue que llevase unos calabasos y que se los puçiese en las manos y cabesa, y llevase también un garrote, y que, cuando viniese el águila a picarlo, le diese con él y la mataría.

Conque así lo hiso. Fue y mató las águilas y trajo [570v] los hijos y los presentó a Ochuna Nicoguadca. Viendo pues que ${ }^{35}$ no le pudo matar, trató

34 El quicio hace referencia al juego del tchung-kee. Para una detallada descripción de este juego, véase Culin, 1992 [1907], 485-487 y 512-513.

35 MS: biendo (^des)pues que. 
entonses que se jugase el juego de pelota. Aquí fue donde tuvo prensipio, y es en esta forma:

Envían un correo desafiando al lugar con quien han de jugar, sitando el día y con cuántos jugadores (digamos cuarenta o sincuenta más o menos, según tiene de gente). Ha de ser a mediodía o a las dos de la tarde, y en verano, que en invierno no se juega. Es a onse pelotasos que se tiran a el palo, y ha de ser con el pie. Dareme a entender: Tiene la pelota en la mano, déjala caer y, con el pie, levantándole y dando para arriba un sapataso, tira la tal pelota, que será del tamaño de una bala de mosquete (algo mayor). Si se queda en el palo vale dos. Júntanse todos hechos una piña, desnudos como su madre los parió, menos un braguerillo de gamusa que les tapa sus vergüensas, y entrensado el cabello. Y un prensipal echa esta pelota en medio de todos, que están en pie y con las manos levantadas. Cae en mano de alguno y, a puras fuersa[s] unos con otros, caen unos sobre otros, y a éstos suben por sus cuerpos, hasiendo de ellos escalones, y otros por las caras o cabellos o barrigas, conforme están, sin reparo ninguno, para entrar, ya dando patadas, sea en cara, sea en cuerpo, sea donde se fuere por otras partes, tirando de los brasos o de las [571r] piernas, sin reparo en que se pueden desconsertar. A otros les están llenando la boca de tierra.

Viénese a deshaçer este montón. Allí quedan cuatro o sinco tendidos como atunes. Allí están otros quejándose del gasnate, porque como la [tierra] suelen tragar, se la haçen gomitar a puro apretarle el gasnate o [a] patadas en las barrigas. Allí están otros con un braso quebrado o una pierna. Esto es, como he dicho, a mediodía, en este exerçisio que, según lo cuento, es un bosquejo para lo que sucedió, porque ellos son un fuego vivo por su compleçión. A mediodía con este exerçiçio ${ }^{36}$ y sol, ¿qué tales quedarían aquellos cuerpos? Y los resuçitan a puro balde de agua. Véase qué mediçina es ésta para cuando tienen los poros abiertos. ¿Qué podían vivir estos miserables? Así se iban consumiendo y se ha consumido esta naçión. Y todo esto es un bosquejo.

Fue el correo, que era de presecto que había de ir en la forma siguiente, que era en figura de tosawi, ${ }^{37}$ que es el tejón, con su rabo y tisnado de prieto, unos como cuernos en la cabesa, y la cara tisnada de colorado, y el cuerpo tisnado de prieto, y unas como rayas de colorado, que pareçían a el mesmo demonio (que de mí digo que cada ves que los vía se me representaba la figura del diablo). Y era seremonia que, si no admitía el desafío, se quitaba los trastes y venía como corrido, sin entrar en la plaza, sino con todos los trastes recogidos [571v] y colgados en un palito a el hombro. Pero, si admitía, entraba en la figura dicha y con cascabeles o campanillas o senserros, haçiendo grande armonía de estos trastes, y al trote, para que lo salieran a reçibir.

36 MS: exerçisio. Pero a la letra «s» se le ha añadido una cedilla.

37 MS: dosuai. Pero es errata por probable apalache tosawi, «el tejón; choctaw šawi; koasati sawá; mikasuki sā:w-ī». Kimball, 1988, 396. 
Habiendo admitido el desafío llamó Itonanslac a todos sus vasallos, que eran los leones, lobos y osos, todos los animales prietos y fuertes. Y así tienen por sobrenombre Kowi Juan. Kowi ${ }^{38}$ es el león, Nita Agustín es el oso, y así caeteris paribus, etc. ${ }^{39} \mathrm{Y}$ estaban entendiendo que los jugadores proçedían y desendían de la plaza y el palo de pelota, que éstos eran sus propios padres que los engendraron. Y así éstos entraban todos tisnados de prieto representando estos animales, y la parte contraria pintada de otras colores, a diferençia de éstos, representando otros animales como el venado y el sorro, etc. Todos vienen y entran en la plaza desnudos como sus madres los parieron, menos un braguerillo con que tapan sus vergüensas. Y es a donde más concurso de gente se halla, como adelante diré, y de cuando en cuando dan unos aullidos como lobos. Y con estas figuras considere ahora, por amor de Dios se lo pido, cada uno, qué pareserían y a quién no había de desconsolar ${ }^{40}$ semejante juego [y] si esto podía dejar de tener algo encubierto de sus infidelidades.

[572r] Teniendo juntos sus jugadores, Itonanslac les dio los presectos para que no perdiesen. Y son los que se siguen y ellos han guardado inviolablemente, que me consta. Y si se dejaba de haçer tenían por cierto perderían. Y para prueba diré lo que me pasó en sierto lugar que, por auçençia ${ }^{41} \mathrm{del}$ padre, iba a desir misa los domingos reçién venido ${ }^{42}$ a la tierra. Y los de este lugar habían perdido unos dos juegos considerables y estaban para jugar otro aquel domingo, y hallé un soldado que hoy es capitán reformado y me dijo que estaban los indios muy desconsolados porque tenían por sin duda perderían. Y pregunté la causa y me dijo porque no se juntaban de noche a dormir su pelota, y que no les abrían la igleçia como otras veses, etc. Reparé en todo esto y dime por desentendido.

Primer pres[e]cto: Que los jugadores no durmieran la noche antes que habían de jugar. Doyme a entender: Si jugaban el domingo, el sábado en la noche no habían de dormir, sino velar los jugadores y exersitarse en lo que adelante diré, porque si uno tenía una cosa en la mano y se dormía era fásil que otro se la quitase. Y así, si se dormía era señal que perdería. Y así lo haçían, que toda la noche se estaban en vela, todos juntos, amontonados y sentados en unos bancos rasos, hablando muy quedo. Y de en cuando en cuando salían $[572 \mathrm{v}]$ con unos aullidos de lobos. Y esto ${ }^{43}$ era a veses a

38 MS: cuy Juan. cuy. Es corrupción del apalache kowi, «puma», comparable al chocktaw kowi, koasati kowí y mikasuki kō:w-òs-ī. Kimball, 1988, 394. Nita se traduce, como el MS indica, por «oso». Kimball, 1988, 395.

39 MS: seteris pauper. Es corrupción de caeteris paribus, «[siendo] las demás cosas igual», «el resto [es] similar».

40 MS: no abian de desconsolar? Elimino la «n» y el signo de interrogación que sigue a esta palabra porque el verbo principal de la oración («considerar») requiere pregunta indirecta.

41 MS: auçiençia.

42 MS: venido venido.

43 MS: estos. 
medianoche o más tarde. Y luego los perros del lugar, que no son pocos, les acompañaban aullando. Y, en el silençio de la noche, jusgue ahora cada uno qué pareçería. Yo de mí digo que me daba horror y espanto, y me maravillaba que aquello pudiese ser bueno, que era impuçible dejar de encubrir o tener algunos abusos o super[s]tiçiones. Y habiéndolo preguntado a algunos padres me desían que les daban la seña para cuando estuviesen jugando amontonados, pero no por eso dejaba de sentir lo contrario, porque ¿qué tenía que ver la seña a no dormir y de cuando en cuando dar aquellos aullidos?

Lo segundo: Que mandasen a cuatro o sinco viejos que durmiesen y que lo que soñasen lo dijeran a el prinsipal o a quien vino [con] el correo de pelota luego por la mañana. Y si dise que soñó que por tal parte entraba el enemigo y los mataba y les quitaba lo que tenían, es mal sueño; por aquella parte no se han de poner los asientos a los jugadores, porque perderían. Y si el otro desía que por tal parte soñó que entraba un caçique muy galán, con muchos dones que repartía entre ellos, era buen sueño; por aquella parte se ponían los asientos a los [jugadores]. ${ }^{44}$

[573r] Lo tersero: Que se había de haçer candela nueva y que a ella no se había de llegar ni usar para otra cosa más que para lo que se diputaba, porque de usarse tenían por sin duda perderían, aunque fuese para chupar tabaco. Y de ella habían de llevar al juego de pelota en unos mechones de guano ensendidos, la cual ponían delante de sí.

Lo cuarto: Que en entrando en la plaza no entrasen con toda la gente que habían consertado para jugar. Verbigraçia: Si consertó cincuenta personas, entrase con cuatro o sinco menos. Y cuando os pregunten si tenéis toda la gente junta, desid que no, que os faltan tantos. Y si os mandaren entonses meter de los mosos o demás gente que a vos os pareçiere, teneldo por buena señal que ganaréis. Y así lo hiso y lo han estado haçiendo. Y, lo peor, que ha sido a nuestra vista esto y todo lo demás que se verá. Esto es en todos los lugares de Apalache, siendo en toda la provincia común [e] igual. Y por tenerlas por simplesas suyas, por tal les pasaban, siendo nosotros los simples en efecto.

Entraron en la plaza, y preguntándole ${ }^{45}$ si estaba la gente junta y cabal dijeron los de la parte de Itonanslac que no, que les faltaba tanta gente. Dijeron los contrarios que metiesen de aquellos mosuelos que había por allí. Llamaron a Eslafiayupi, el hijo de Nico Taijulo, [573v] el que mató el águila y engañóo ${ }^{46}$ las víboras, etc., que estaba como enfermo, arrimado a un poste, arropado con una manta de plumas. Y en entrando en el juego se trabó la batalla. Y habiendo llegado los de Itonanslac a siete, dio un tronido grande Eslafiayupi y quedaron todos espantados. Y fue conoscido Eslafiayupi por

44 Falta en el MS, pero la palabra se ha utilizado dos líneas más arriba.

45 MS: preguntandose.

46 MS: engano. 
Nicoguadca, que es el rayo, hijo de Nico Taijulo y del Sol, que es Nico. Y desde entonses quedó por agüero que el primero que llegaba a siete ganaría, porque le ayudaba Nicoguadca, y los contrarios luego desmayan. Y esta historia se les iba en contar toda la noche, ya en el bujío, ${ }^{47}$ ya debajo del palo de la pelota.

Habiendo perdido Ochuna Nicoguadca a la pelota desafió a Nicoguad$c a$ a jugar a el quisio, que es el juego que al prensipio dije jugaban todas estas naçiones, que es con una piedra y dos varas. Pues, como digo, desafió a Nicoguadca. Y, habiéndole ganado todo cuanto tenía, disen que trató de meterlo a trampa. Y fingió $\mathrm{el}^{48}$ tal Ochuna Nicoguadca que tenía sed y quería ir a beber. Y disen dio Nicoguadca con la vara de punta y en el suelo, y hiso brotar agua y díjole:

— «Bebe aquí».

Fingió tener neseçidad corporal de usar de su albadañar, ${ }^{49}$ y Nicoguadca le formó un montesillo y díjole:

— «Hasla aquí».

Y por postre dijo iba a ensender un tabaco. Y entró en una casa y abrió un agujero [574r] y se fue a Apalachocole. Y entonses Nicoguadca fue en su busca con sus tascayahs..$^{50} \mathrm{Y}$ él (disen) le formó muchas nieblas, fríos, hielos, etc., mas con todo lo vençió y lo mató a él y a sus tascayahs. Y sus vasallos le formaron el palo de pelota que se ve aquí en esta plana, como (mediante Dios) lo iré esplicando. ${ }^{51}$

47 Buhío: «cabaña de América, hecha de madera y ramas, cañas o pajas y sin más respiradero que la puerta» (DRAE), aunque cabe añadir que el tamaño de la cabaña puede ser considerable. Cf., más adelante, «se ponían en el bujío, que vienen a ser las casas de su gobierno» (f. 576v).

48 MS: al.

49 Albadañar, albañar o albañal: «Canal o conducto que da salida a las aguas inmundas» (DRAE).

50 Taskayah es «guerrero», «valiente», comparable al choctaw taska y al koasati kaskí. Kimball, 1988, 396. Los grados eran taskayah, hita taskayah, noroco y niko watka. Hann 1988, 71 y 192; Hann y McEwan, 1998, 35.

51 Este párrafo ha suscitado problemas entre los traductores norteamericanos, lo que ha llevado a varias interpretaciones. Las cuestiones a debate son si Ocona Niko Watka es quien desafía a Eslafiayupi (Hann, Bushnell, Peterson, yo) o viceversa (Granberry), si gana el primero (Hann) o el segundo (Bushnell, Peterson, Granberry, yo), si el que escapa utilizando trucos es el primero (yo) o el segundo (Hann, Bushnell, Peterson, Granberry), y si quien sale victorioso al final es el primero (Granberry) o el segundo (Hann, Bushnell, Peterson, yo). Aun admitiendo que las últimas tres líneas son algo confusas, no veo problemas para interpretar el pasaje. El erróneo «al» que aparece más arriba (y que debe ser corregido a «el») ha sido motivo de mucha confusión, cuando en todo caso hay varios errores del mismo tipo en el MS y, como sabemos con absoluta certeza que es Eslafiayupi (Niko Watka) el que da con la vara en el suelo, forma un montecillo, etc., no cabe otra interpretación que admitir que Ocona es el que pierde, el que intenta escapar con trampas (si no hubiera perdido, ¿para qué escapar?) y el que al final es asesinado por el joven Niko Watka. Adicionalmente, recordemos que Eslafiayupi (Niko Watka) sigue vivo unos folios más adelante, y que al principio de la historia se describe la profecía según la cual Eslafiayupi matará a Ocona, se dice que Eslafiayupi superaba a todos en su destreza en el juego y se relata cómo Ocona ya intentó engañar a Eslafiayupi con otras tres trampas. 


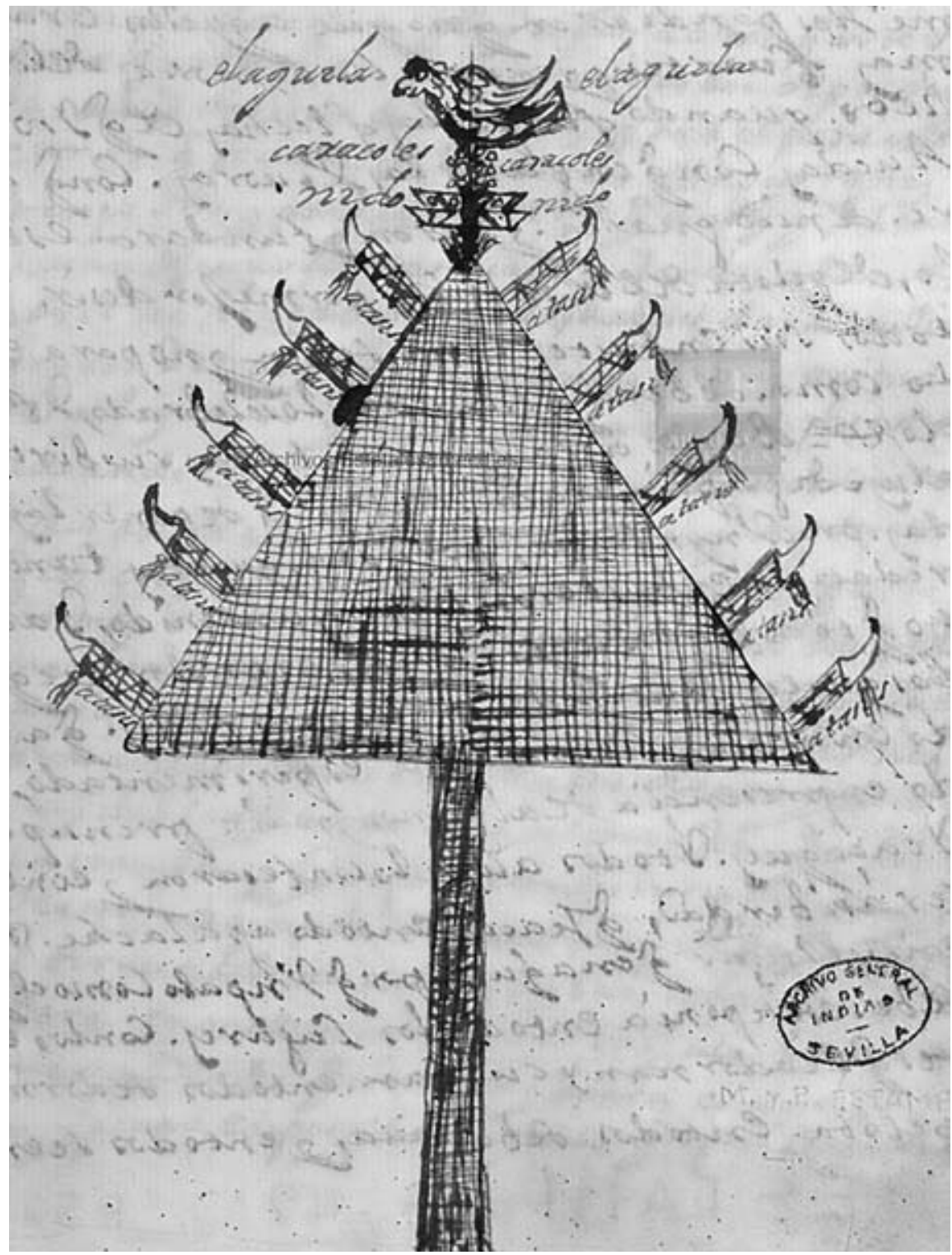

Poste para el juego de pelota. ${ }^{52}$

52 Archivo General de Indias, Escribanía de Cámara, 156A, f. 574r (detalle). Anteriormente publicado en McEwan, 2004, 673. 


\section{DAVID ARBESÚ}

[574v] De él $1^{53}$ con que mató el águila. Al pie de este palo se había de poner o enterrar una cabellera de persona muerta en memoria de Itonanslac, su fundador, bisagüelo de Nicoguadca. Los palillos que le estofan habían de ser de sasafrás ${ }^{54}$ y no de otro palo. Con parrones lo habían de levantar y no con otra cosa, aunque hubiera maromas, como a mí me sucedió. Dándoles sogas me respondieron que no, que aquéllos eran más fuertes, y era por la memoria de los que llevó [Eslafiayupi] cuando fue por las flechas, de que hiso las ruedas con que engañó las víboras. Con que ad honore $[\mathrm{m}]$ de Nicoguadca hisieron y fundaron este palo de pelota (del demonio, por mejor desir) con todos sus embustes, como se ven, y no para en esto, como se verá. Y esto ha sido lo selebrado y festejado, etc.

Vamos ahora sacando todas sus virtudes, a lo que digo primeramente de ellas que, de ponerlas todas, era un infinito, porque son cuantas tantos catredáticos embusteros tienen y han tenido. Y advierto que todo lo que va aquí escrito es por dos atequíes ${ }^{55}$ los cuales son tenidos por los más fieles que ha habido entre ellos, como se tiene esperimentado. Y ha sido en presençia de algunos indios prensipales y caçiques, y todos a uno lo confesaron y confiesan ser así verdad que se haçía en todo Apalache, no más en este lugar que en aquél, porque un palo como el que se ve, ése se ponía en todos los lugares, con los embustes que le adornan y cuelgan. En todos se dormía la pelota, en todos se bailaba y en todos se entra- [575r] -ba de la suerte que lo he pintado, dando los aullidos que tengo dicho de una mesma manera, y con unas mesmas seremonias se jugaba en todos los lugares. Esto digo para lo de adelante.

Abusos y agüeros y superstiçiones para levantar el palo de pelota, que fue su mayor fiesta.

Primeramente, cuando lo tenían armado sin los palillos que le estofan (digamos en embrión) había de estar la corona de él para donde nase el sol. Y para aquella parte se le haçía la cava, porque si para otra parte se ponía o se haçía tenían por agüero habían de perder. Y el águila había de estar mirando para el poniente.

Lo segundo, que se había de levantar con parrones, como lo tengo dicho.

Y porque lo tersero, que antes que se levantara habían de estar los tascayahs bailando al son de un tamboril alrededor del palo, y a veses dando aullidos como perros y otras veses ladrando y otras haçiendo como lobos.

Lo cuarto, que después de haber bailado estos tascayahs habían de entrar seis mujeres con otros seis tascayahs, y habían de estar bailando hasta que se puçiese el palo.

5. Que los hombres habían de tirar por una parte los parrones y por la otra las mujeres, y no había de quedar ninguna en su casa.

53 Este párrafo y el anterior quedan divididos por el bosquejo del poste, y es obvio que Hernández de Florencia se ha saltado parte del texto.

54 MS: salsafras.

55 Atequíes se refiere a intérpretes, en este caso Diego Salvador y Juan Mendoza. 
Lo sesto, que una mosuela (no había de ser casada) había de estar con un vilorto, que venía a ser una caña de alto de vara y media, rajada y doblada, como se ve al margen, ${ }^{56}$ que es con lo que las mujeres juegan también su pelota. Y ésta había de estar haçiendo seremonias debajo del palo como que tiraba, etc., mientras lo iban levantando. Disen que era en memoria de Nico Taijulo, la madre de Nicoguadca.

7. Que estando ya para endereser al tal palo y poner en peso, el $u \sin [j]$ ulo, que significa «hijo ama- [575v] -do» (así llaman a el hijo del caçique, vivo [o] muerto), este tal había de ser hijo del caçique prensipal del lugar, porque estos lugares tienen tres [o] cuatro lugarsitos, y cada uno tiene su caçique. Verbigraçia: San Luis es el lugar pren[sipal y ${ }^{57}$ tiene agregados a sí a San Francisco, San Bernardo y San Augustín, conque el usinjulo del lugar de San Luis había de ser el que había de haçer la seremonia que diré. Había de haçerle al palo cuando lo iban levantando — como he dicho- el gua, que es como si dijéramos la salva, y es en la forma siguiente: Poniendo las manos juntas, de plan[o], derechas, desía tres veses gua, gua, gua, que es la salva que se le hase a los caçiques, y luego le había de echar caçina. ${ }^{58}$ Repárese ahora que este usinjulo es la persona que ellos más aman y reverençian y respetan. Pues, este haçer el gua, dar caçina a este palo, etc. ¿qué misterio tiene? Es idolatría. Era su ídolo. ¿Si [a] algunos les parese que no? ¿Y si ent[i] en[den] ser lísito esto? A mí no, a Dios graçias. Y así, primero perderé la vida que tal consienta.

Lo octavo, que aquella noche, antes del día que habían de levantar el palo, había salvoconduto para que cualquiera pudiese tocar y palpar, etc. a cualquier mujer que se fuese, fuese casada o soltera, como viniese al baile aquella noche, la cual no se había de defender, porque si no consentía tenían por çierto que todos los juegos que en el tal palo que levantaban se jugaran se habían [576r] de perder, por cuya causa andaban los prensipales solíçitos, rogándoles no se defendiesen, tuviesen lástima de ellos y de sus maridos, hermanos, etc. porque perderían lo que tenían. Y esto me lo aseguraron que ellos se lo habían contado. Pregunto: ¿Este consejo, cuyo es? ¡Oh, poderoso Dios!

56 En el MS no hay ningún dibujo al margen. Hann afirma que en 1976 consultó una segunda copia en la Universidad de Florida en la que aparecía un dibujo. Hann, 1988, 339 n. 15. Además, en la bibliografía del mismo estudio comenta que el nombre del autor aparece escrito mal «en una de las copias de este manuscrito». Ibidem, 428. Ningún otro autor hace referencia a esta copia, y nadie en la biblioteca de la Universidad de Florida ha podido darme noticia de ella. Si de veras existe una segunda copia del MS, no se entiende que Hann no haya cotejado su texto con el de AGI, al menos para solucionar los múltiples problemas de interpretación que le salen al paso.

57 Hernández de Florencia se ha saltado palabras. Sin descartar que falten otras reconstruimos la lección más obvia.

58 La casina se refiere a un té preparado a base de hojas y ramas de la Ilex vomitoria Ait o «casina de la Florida» que tenía propiedades regurgitantes. Como se explica en el MS, la bebida era utilizada con fines religiosos, medicinales y sociales. Véase al respecto el reciente estudio de Hudson, 2004 . 


\section{DAVID ARBESÚ}

Lo noveno, que a el pie de este palo de pelota se había de poner un casco o cabellera de persona muerta — como ya lo tengo dicho- en memoria de su fundador, de Itonanslac, el padre de los jugadores de pelota.

Abusos, agüeros y superstiçiones que tenían cuando jugaban este endemoniado juego.

Lo primero, que había de ser la pelota de gamusa, y que fuese de las garras, porque desían que el venado tiene en los pies y las manos toda la fuersa, y siendo la pelota de las garras le infundía sus fuersas al que la cogía. Y esta pelota la llenaban de barro y la ponían a secar, conque después no había diferençia de ella a una bala.

Lo segundo, que el $u \sin [j] u l o$, hombre o mujer (ya tengo declarado quién es el usinjulo, que es hijo de caçique, y en su idioma dise «amado hijo»), y este tal luego se pone a ayunar. Y es en la forma siguiente: No ha de comer más de una poca de onsla, que viene a ser como atol ralo. ${ }^{59} \mathrm{Y}$ no ha de comer otra cosa. Y de esto tiene número señalado de las cucharadas que ha de beber. Y de aquella onsla nadie había de llegar a beber, que era vedado, porque perderían. Ni de la candela con que se cosía ${ }^{60}$ se había de usar para otra cosa más que para coser esta onsla y beber tabaco. Y el tal ayunador, el tabaco que chupaba no había de ser del nuestro, sino del suyo, que llaman hacchuma finha, mesclado con una hoja que llaman atabac. ${ }^{61} \mathrm{Y}$ aunque usan de esta hoja siempre cuando no tienen tabaco, o para mesclar el que tienen, con todo no había de chupar su hacchuma [576v] finha ${ }^{62}$ sin esta hoja. Y esta candela en que se cosía esta onsla había de ser nueva.

Lo tersero, en la pelota le solían echar en algunos lugares cabellos de gente que habían matado. Disen que era hechiso.

Lo cuarto, que el caçique del lugar que jugaba había de ayunar la noche antes del juego en esta forma: A puestas del sol (o más tarde) se ponían en el bujío, que vienen a ser las casas de su gobierno. Ponen los asientos para los jugadores, que son rasos, unos palos cavados por debajo, sin pies. Y se han de poner enfrente del lugar con quien jugaban. Dareme a entender: Si el lugar caía para el norte, ponían los bancos para el sur, de suerte que viniesen a estar la cara para el norte. Y los bailadores habían de salir por la parte del sur dando jipidos ${ }^{63}$ y señalando la parte con el braso tendido. Y el tamborilero y el de la maraca y las mujeres, todos habían de estar enfrente del lugar con

59 La onsla es una bebida a base de maíz típica de los indios del sudeste norteamericano. El atol o atole es «bebida caliente de harina de maíz disuelta en agua o leche», del náhuatl atolli, «aguado» $(D R A E)$.

60 Entiéndase «cocía»y, así, más adelante «cocer», etc.

61 La hoja atabac no plantea mayores problemas. Para hakcoma finha, «tabaco cermonial», «tabaco verdadero», compárese con el choctaw hakcoma, el koasati hakcommí o la palabra del creek semínole hicí. Kimball, 1988, 392.

62 MS: acchumafi- fina.

63 Jipiar: «hipar, gemir, gimotear» $(D R A E)$. 
quien jugaban, porque desían que si les volvían las espaldas era señal que habían de perder, conque detrás de estos bancos de los jugadores se ponía el cacique ayunador, y entre el cacique y los jugadores se ponía candela, y había de ser nueva. De ésta no se había de usar más que para que el caçique chupase tabaco, y que había de ser del suyo, hachuma finha, y no del nuestro. Y que de forsiori ${ }^{64}$ había de ser mesclado con la hierba o hoja atab $[a] c$ que arriba dije, el cual caçique ayunador ${ }^{65}$ había de estar sentado toda la noche en este banco ${ }^{66}$ dándoles consejos a sus jugadores, etc., diciéndoles tam- [577r] -bién que eran hombres y no mujeres, que en cogiendo la pelota no la largaran aunque los matasen. Y ellos desían maquiliqui. ${ }^{67} \mathrm{Y}$ esto yo lo oí no una, sino muchas veses, y no en San Luis. Así será, como de hecho era. Y de cuando en cuando, muy a menudo le habían de estar dando casina, aunque él no la quisiese. Lo que hasía, estando repleto, lansarla. Y siempre chupando tabaco del que tengo dicho, y a veses hojas. Mas si era hombre fuerte este caçique (y aunque no lo fuese) entraba $\mathrm{al}^{68}$ juego habiendo tenido este exerçisio.

Lo quinto, en teniendo notiçias el lugar contrario de estos ayunos, luego hasían la chacalica, que, a nuestro desir, «contra de contra». Y — como digo - siendo notiçiosos de estos ayunos o de otras cosas que haçían (que para ello tenían sus espías, o de hombres o mujeres), luego el lugar contrario procuraba matar una gallina de monte o una ardilla o tejón. Uno había de ser de estos animales, que los demás desían no servían. Y luego lo ponían a coser, de tal suerte que largaba los güesos y quedaba hecho una masamorra. ${ }^{69}$ Esto, de tres o cuatro días hecho, lo echaban en vaçijas y lo llevaban a la parte donde se tenían los cuerpos y se pintaban. Y con este caldo jediondo deshaçían el barro o tisne o fuese de lo que usaban para teñirse. Y era tan jediondo que ellos me diçen no lo podían soportar. Y que, en entrando en la plaza, que la parte contraria los olía, desían que luego desmayaban, porque ya el ayuno no tenía fuersa, que habían hecho la contra, etc.

[577v] Lo sesto, cuando venía el correo y desía ya por último la gente que había de jugar, contaba la del lugar contrario y otros tantos palitos del tamaño del dedo de la mano, y todos juntos, hecho un hasesito, ${ }^{70}$ los amarraba y echaba en una olla. Y mandaban haser casina, y no había de ser de las de

64 Es corrupción de a fortiori, «por fuerza».

65 MS: ayudador. Es Hernández de Florencia quien corrige la lectura escribiendo la «n» encima de la «d».

66 MS: banço.

67 Según Kimball, quien no relaciona el término con el MS de Paiva, makahlici significa «mantener abiertos los ojos». Kimball, 1988, 394. Quizás en este contexto aluda al precepto de no dormir la noche antes de un juego.

68 MS: el.

69 MS: hecho v vna masamorra. La mazamorra es una especie de puré, galleta rota o «cosa desmoronada y reducida a piezas menudas, aunque no sea comestible» (DRAE).

70 Es decir, un haz pequeño. Haz: «porción atada de mieses, lino, hierbas, leña u otras cosas semejantes» (DRAE). 
la costa del mar, que es la que comúnmente se bebe, sino de la del monte de acá arriba. Y hecha la caçina la echaba en aquella olla con el has de palillos en nombre de los jugadores contrarios, para que se puçiesen ${ }^{71}$ flojos y no tuviesen fuersas. Y si esta olla acaso la destapaban mientras jugaban, tenían por sierto perderían.

Lo sétimo, la noche que velaban la pelota preguntaban los prensipales si había alguno o algunos que se sentían con temor o miedo. Y si lo había enviaban un hombre de su satisfaçión al lugar contrario con quien jugaban y llevaban una cabellera de persona muerta para enterrar debajo del palo de pelota donde habían de jugar, o que si pudiera la echase en la candela de los jugadores. Si podían conseguir esto último tenían por sin duda que no perderían. Y estaban tan siegos que, aunque perdían, no se desengañaban.

Sépase ahora ${ }^{72}$ que es cuento graçioso, en qué paró su amado y querido Nicoguadca. Disen que, cuando se quiso morir (o lo fingió, por mejor desir, para engañarlos) [578r] llamó a todos sus prensipales. Y teniéndoles juntos les dijo:

— «Ya yo me muero. Ahora, el que quisiere ser Nicoguadca y quedar en mi lugar, ha de matar siete tascayahs y tres hitas tascayahs, y habiéndolo conseguido será Nicoguadca».

Como me han dicho mis hijos, los de San Luis, que no ha mucho tiempo murió un indio llamado Talpagana Luis que traía un bastón del tamaño de un venablo, y en la punta unas cabelleras y pintados algunos en el tal palo. Y pregunté qué era aquello y me dijeron que era hita tascayah, y ahora me han confesado que era Nicoguadca. Siendo yo padre de esta doctrina el año de [mil seiscientos] setenta y uno, salí por guardián del convento de San Augustín. Y en este tiempo, siendo padre de ella el reverendo padre Francisco Maíllo, murió este indio. Y aunque me cuentan que dijo había de venir y quemar el palo de pelota, como por justos juiçios de Dios Nuestro Señor aquel año cayó un rayo y lo quemó a éste de San Luis, y otro año cayó otro y quemó el de Bacuqua, habiendo sucedido dos años antes haber caído otro en Patale y quemado otro palo. Pasó adelante con su rasonamiento y díjoles:

— «Lo que os encargo es que, luego que yo muera, mi cuerpo lo echéis en unas ollas grandes con calabasas, melones y sandías, y las llenéis de agua y las pongáis al fuego hasta que hiervan muy bien, para que con aquel vapor yo salga en humo convertido. Esto es para cuando tengáis vuestros sembrados yo me acuerde de vosotros y os dé agua. Y, así, cuando oyereis tronar es señal que ya yo vengo».

Y así desían que fue y lo hiso. Y hasta ahora (particularmente los viejos) estaban entendiendo que cuando tronaba ya venía [578v] Nicoguadca a

71 MS: puciesen.

72 MS: aura. 
darles agua. Y ¿quién duda que muchos de sus hijos y parientes, siendo ellos tan fásiles, no lo estuviesen entendiendo, mayormente cuando se inoraba, ni se les reñía, ni repregendía? Y estaban en esta seguedad, engañados del demonio, siegos, mudos (no digo sordos), porque, si se ignoraba todo esto, ¿cómo se les había de repregender y ellos oír lo contrario a sus abusos? Pues, por amor de Dios, pido que miremos esto con caridad, y véase - como se verá adelante - si tal juego se podía permitir. Lo que siento es que, después que se ha sabido, han querido contradesir el que no se les quitase. No sé en qué se podían fundar. Demos muchas graçias a Dios en que se les ha quitado, que yo de mi parte no seso ni sesaré. Parese que se me pregunta: «¿Qué motivo tuvo para procurar con tanta eficaçia el que se quitase este endemoniado juego?». Direlo, ayudándome Nuestro Señor: Cuando vino el Ilustrísimo Señor don Grabiel Días Vara Calderón a su visita, vido acaso en este lugar de San Luis los mosuelos jugarlo aquello (de juego, no como lo jugaban con otros lugares). Envió a su secretario que viese aquel montón y aquel modo de juego, y el patearse y subir unos por otros como si fuese por una escalera de piedra. Vino el tal don Pedro y díjole lo bestial que era. Y Su Señoría lo estuvo mirando con toda atençión, y después mandaba que se [579r] derribaran todos los palos, que aquél era juego bárbaro y bestial, y contra toda rasón y en daño del género humano de estos miserables. Yo, con ruegos y súplicas, le pedí suspendiese Su Ilustrísima la execusión [que] por entonses llevó, que por entonses no tenía descubierta maldad ninguna ni teníamos en qué haser piernas (como disen) para podérselo quitar, por haber visto ya çédula de $\mathrm{Su}$ Magestad, que Dios haya, en que mandaba que a los naturales de estas partes no se les quitase nada de sus bailes ni otros juegos, no siendo contra la ley de Dios Nuestro Señor y educaçión de ellos.

Hablé como católico, conque Su Ilustrísima me hiso toda merced con que yo, por las causas referidas y otras, me pareçió me había fundado en rasón, aunque mis reselillos no me faltaban. Después, otro año, que fue el de [mil seiscientos] setenta y seis, estuvo a pique de perderse la provincia, originado todo de este juego. Pulsome la conçiençia. ${ }^{73}$ Empesé a escrupulear en ello y haserme causa de todo lo que podía suçeder, pues el señor obispo había mandado cortar los palos y, a mi ruego, por asegurarle yo que no tenía ningún riesgo, Su Ilustrísima suspendió su mandato. Fue Dios Nuestro Señor servido que me hallase por padre en un lugar que puedo desir hay indios de rasón y satisfaçión. Llamé los que yo tenía por más fidedignos y pregunteles el prinçipio y origen de este juego, conque, a Dios infinitas graçias, fui sacando lo que se ha visto de ellos mismos, con los dos atequíes, ${ }^{74}$ todo esto y mucho más que dejo por no ser cansado. Y a otros atequíes (y solían venir aquí

73 MS: consiençia. Pero a la letra «\$» se le ha añadido una cedilla.

74 MS: atequiquies. 
a San Luis) [579v] se lo desía y me confesaron ser verdad que se hasía esto y mucho más. Y el prinsipio de este juego y su origen dise Diego Salvador que se lo contó el caçique de Samoche, que hoy vive, y un hinija de Oconi, ${ }^{75}$ y después él en Ivitachucho se sertificó de todo. Y Mendosa me ha dicho que su padre le contó toda esta historia, y que vido levantar un palo en San Diego, un lugar de Tomole, y allí le vido echar caçina y haçer el gua a el palo el usin[j]ulo. Y los demás disen que eso es inmulisla ${ }^{76}{ }^{76}$ como dijéramos ${ }^{77}$ es costumbre suya en Apalache. Luego me hallé amparado del gobernador don Pablo de Hita Salazar y de nuestro muy santo padre provincial fray Francisco Perete, que lo admitieron como debían, conque, asegurado a que lo que mis hijos me han dicho que era verdad, y como vide en una junta de caçiques que hiso el capitán Juan Hernández para darles los agradecimientos de parte del gobernador por lo bien que habían obrado los caçiques que habían derribado los palos y puesto en su lugar la Santa Cruz, se lo dijo en mi presençia Diego Salvador a todos ellos, y todos dijeron aún que era verdad, presente[s] el capitán Juan Hernández y el capitán Juan Sánchez de Uriza y otros muchos. Y, no obstante, no ha dejado de haber sus contraverçias, ${ }^{78}$ no por parte de los indios. Diré una que es la más fundamental, y es que dicen que era verdad que las tenían, pero que ya no usaban de ello.

A lo cual respondo que ¿por causa de quién lo dejaron?, que ¿quién se lo dio a entender?, que ¿quién se lo riñó?, que ¿si no se vía actualmente el palo ad honorem ${ }^{79}$ Nicoguadca?, que ¿si no los vían dormir la pelota o velarla?, que ¿si no los vían en- [580r] -trar tisnados de la suerte que tengo dicho? Y esto hoy en día, hasta el postrero que se jugó. Pues, siendo esto así, ¿Cómo lo dejaron, cuando vían que le aplaudían? ¿Cómo ellos, de su motu [propio], ${ }^{80}$ lo habían de dejar, cuando estamos mirando y palpando que sus médicos, que curan con mil bellaquerías, los están riñendo y castigando, así los padres como el teniente? Y aun haçiéndolos forsados por tiempo por que se enmienden y, no obstante, no hay remedio el que lo dejen, pues hay los que (no se inora), siendo el indio hijo del temor, ¿cómo ellos, de su motu propio, habían de dejar en cosa de tanto interés este juego, cuando se conose ser el indio tan interesado y cuando ellos a voses lo están confesando que es verdad? Sea Dios bendito, el juego se ha quitado con todo amor y sosiego.

75 El término hiniha equivalía en castellano a mandador y designaba al indio más poderoso por debajo del cacique. Hann y McEwan, 1998, 13. Aparece en el diccionario de apalache como «término ceremonial». Kimball, 1988, 392.

76 De significado incierto, a no ser que signifique, como el MS dice, «es costumbre suya».

77 MS: dijerammos.

78 Entiéndase «controversias».

79 MS: ad onoren.

80 MS: de su metod. Es errata por posible abreviatura en el antígrafo (de su motu $p^{o}$ ). La lección es fácil de reconstruir por exigirla el contexto y la sintaxis, y porque se repite claramente cuatro líneas más adelante. 
Los mismos indios a voses [confiesan] lo bien que les está, así para su alma como para sus cuerpos. Démosle a Dios mil graçias por tan grande benefiçio.

Veamos lo que resultaba de jugar este infernal juego de pelota:

Lo primero, las muchas discordias y poca paz que de este endemoniado juego se originaba. Nadie me negará esta verdad, a lo cual disen que es materia de buena política que estén unos lugares con otros encontrados. ¡Política del demonio!, ¡gobierno lusiferino!, pues se opone a la dotrina y enseñansa de Cristo: «Amados diçípulos, mi paz os dejo, mi paz os doy». ${ }^{81}$ Por última prenda la deja encargada. Véase lo que anunçia el ángel a los pastores: «Gloria al alto Dios y paz a los hombres de buena voluntad». ${ }^{82}$ Pues ¿qué política puede ser buena, la que no quiere paz, sino discordia? ¿Cuya es esta [580v] doctrina $?^{83}$ Para llorar con lágrimas de sangre es tal seguedad. Dísenme ser una de las rasones que le escribieron al gobernador pidiéndole no quitase el juego. No sé qué verdad sea, sólo sé que me lo dijo persona fidedigna.

3. ${ }^{84}$ Ser juego bárbaro de gente que sólo sin el conosimiento de Dios lo podía jugar. Por muchas causas que iré dando, y por los muchos cojos, pierniquebrados, mancos, tuertos, liçiados ${ }^{85}$ de costillas y otros güesos quebrados, como hoy actualmente los estamos mirando en la provincia. Y no pocos, sino muchos. Y de algunos que en dicho juego han muerto, de dos podré dar rasón, que me consta, en la plaza de San Luis.

4. Que, por lo mal que ya se jugaba, estaba arr[i]esgado a suçeder no una, sino muchas desgraçias, como se vido el año de [mil seiscientos] setenta y seis en sinco juegos suçesivos. Ninguno se acabó, por ser una guerra viva, y se tomaba de mejor partido se dejase. Y no hay duda hubiera[n] suçedido desgraçias si no se hubieran hallado soldados en los juegos. ¡ Y diçen es buena política ésta! No deben de acordarse de las palabras que dijo el evangelista Juan a sus diçípulos cuando sólo les desía que se amaran unos a otros y ellos, reparando, le dijieron: «Maestro, sólo nos enseñas que nos amemos unos a otros». Y les dijo: «Y si eso haséis, sufiçid». ${ }^{86} ¡$ Ésta puede ser buena política!

81 Juan 14:27: «Pacem relinquo vobis, pacem meam do vobis» (Vulgata).

82 Lucas 2:14: «Gloria in altissimis Deo, et in terra pax hominibus bonae voluntatis» (Vulgata).

83 MS: esta do- doctrina.

84 El autor pasa del punto uno al tres, con lo que la numeración es incorrecta.

85 MS: liciados.

86 El mandamiento aparece en Juan 13:34 y 15:12-17, pero la anécdota no es de la Biblia, sino de los comentarios de San Jerónimo a la epístola paulina a los Gálatas, donde se relatan los últimos días de San Juan en Éfeso: «Beatus Joannes Evangelista, cum Ephesi moraretur usque ad ultimam senectutem, et vix inter discipulorum manus ad Ecclesiam deferetur, nec posset in plura vocem verba contexere, nihil aliud per singulas solebat proferre collectas, nisi hoc: Filioli diligite alterutrum. Tandem discipuli et fratres qui aderant, taedio affecti, quod eadem semper audirent, dixerunt: Magister, quare semper hoc loqueris? Qui respondit, dignam Joanne sententiam: Quia praeceptum Domini est, et si solum fiat, sufficit». Lessing, 1990, 494. Obsérvese cómo se mantiene la forma latina sufficit en el calco «sufiçid». 
5. Que como el indio fuese jugador de pelota le cavaban sábana, le hasían casa y garita, tenía salvoconduto para haser cualquier bellaquería, $\mathrm{e}^{87}$ aunque fuese la que se fuese, todo se lo disimulaban y encubrían los caçiques y prençipales ${ }^{88} \sin [581 \mathrm{r}]$ atender ${ }^{89}$ a la ley de Dios, sin darle parte al religioso ni al teniente, temiendo que si lo castigaban se les iría a otro lugar. Valga la verdad, todos la confesamos.

6. Que en habiendo este perjudic[i]al juego era de tabla que había de haber jurto, por dejar sus casas y ellas ser tales que no tienen candado ni ferradura. Una puerta que tiene la casa y otra la garita no tienen las más tabla[s], lo más que haçen es ponerles unas ramas y todos se van a ver este infernal juego. Y también porque, a veses, los que apuestan ser tan grandes bellacos que se van con lo suyo y con lo ajeno que ganen o pierdan, y para haberlo de ajustar $^{90}$ ha menester mucho, y a veses no se podía porque no se conosían las personas.

7. Que se perdían muchas labransas suyas y lugares por no cavar a su tiempo, porque no se atendía más que a este infernal juego, que tanto se enviçiaban en él. Él era sentro de todo viçio y maldad, y a veses era nesesario que el teniente de esta provincia enviara chacales (o soldados) a algunos lugares para que no se perdiesen, a mandarles cavar. Y, no obstante, el lugar que tuvo muchas pelotas aquel año tuvo hambre, porque se perdía.

8. Que en diçiendo había juego de pelota todos se desatinaban a irla a ver, fuérase a donde se fuera. El marido iba por una parte, la mujer por otra y, si tenía hija o hijas, cada una llevaba su camino, conque, como fuese para ir a ver pelota, el marido no se lo impedía a la mujer ni a las hijas que fuese con quien quisiese y por donde quisiese. Todo[s] se desatinaban. A mí me aconteçió que, jugando es- [581v] -te lugar de San Luis con Ivitachuco en la p[la]za de Ocuya, que estará cuatro leguas (antes más que menos) de éste, hallarme sólo con el sacristán y un muchacho, sin más gente en el lugar, y al sacristán no le quise dar lisençia, que de dársela ni aun [el] muchacho me quedara.

9. Que, a veses (y las más veses), sin querer jugar algunos pobres indios, ya con ruegos, ya dándole algo que apostase, etc., sin atenderse a lo que de este infernal juego se podía originar, ir, n[i] creser, ni cuánto ${ }^{91}$ era de deserviçio de Dios Nuestro Señor, y lo contrario que era a su Santa Ley, ni se atendía a ser cosecha del demonio ${ }^{92}$ y senso suyo, antes sí se procuraba que se jugase. Y se andaban buscando los jugadores y agasajándoles y acariçián-

87 MS: a.

88 MS: prensipales. Pero a la letra «s» se le ha añadido una cedilla.

89 MS: sin aten-atender.

90 ¿Quizás «ajusticiar»?

91 MS: q<uenta>.

92 MS: cosecha $(\wedge \mathrm{del})$ demonio. Es necesario, no obstante, recuperar la palabra. 
doles, que es lo mesmo que si se agasajasen a hombres viçiosos y haraganes, porque de ordinario el grande jugador de pelota era grande jaragán. No conosco uno sólo en todos los lugares que he estado administrando, ni vine ayer (como disen), que habrá catorse años que entré en la tierra, y de estos catorse sólo he estado siete en San Luis, los demás he estado en otros lugares doctrinando o, por mejor desir, administrando, porque yo ¿qué doctrina podía enseñar? Y así, a Dios graçias, nada inoro de esto, y todo lo he visto y a los más conosco de la provincia.

Vamos sólo a lo que vamos, y es cosa redícula y frívola la que diçen que se levantaría la tierra y no cavarían ni trabajarían los indios. Esto alude a lo del Japón: Cuando [el] santo [582r] padre Francisco Javier convertía los reyes $\mathrm{e}^{93}$ grandes, les pronosticaban sus bonsos que habían de perderse sus reinos, que los vasallos les habían de perder $1 \mathrm{a}^{94}$ obediençia y habían de irse a otro rey, y a la plebe que se convertía les pronosticaban hambre y guerras, etc. Paréseme que esto alude a aquello, pues por quitarles un juego tan endemoniado, tan sacrílego, de tantas abuçiones y maldades, les pronostican que se levantará la tierra. Y pregunto, ¿a qué venimos?, ¿a ajustarnos con sus leyes o abuçiones ${ }^{95}$ de ellos?, ¿a predicarles la ley evangélica?, ¿a corregirles el viçio?, ¿[a] enseñar la virtud? ¿Quieren, por amor de Dios, por Su Madre Santísima, por las llagas de nuestro padre San Francisco, desir una sola virtud que tenga el juego de pelota que estos jugaban? Díganmela, que yo, por una sola que me señalen, callaré. No me la han de desir. Y, así, no callo. Bien aviada estaba la Igleçia de Dios si por temores se hubiera dejado de predicar el Santo Evangelio y corregir y reñir el viçio y enseñar la virtud. No hay dónde echar mano. Y, así, no me espanto topen por esas paredes.

Y por último digo [que] ya se ha visto que este juego fue inventado por el demonio y por sus efectos se puede conoser, aunque no hubiera más evidençia. Véase los abusos, idola[t]rías [y] discordias ser el sentro de la laçividad, el consumo de la naturalesa de estos pobres, y (lo que más llora mi corasón) ver y conoser ser ésta una gente tan dóçil y reduçida, como en la ocaçión presente (fuera de otras muchas) [582v] lo he visto y esperimentado. Mayormente ahora, pues, ha[bien]do hecho junta de los caçiques prensipales y demás gente de su poçisión de este lugar de San Luis (y no es el menor de Apalache, sino el mayor, y de los más prensipales y leales) y propuéstoles que se quitase el juego de pelota, dándoles las causas y leyéndoles Diego Salvador este cuaderno de su letra, que es el atequí del rey, y habiéndolo oído mis hijos, me dijeron ser verdad todo lo que los atequíes habían declarado, que no todas las cosas de chacalica — chacalica, que es «la contra de la contra»—,

95 MS: abuciones. 
no todo se hasía en ${ }^{96}$ un lugar, pero que uno se hasía aquí y otro allí, y otro allá, que eso era conforme ellos tenían sus maestros, pero que actualmente se estaba haçiendo, según ellos sabían y así han oído. Y antes de resolverme los junté por dos veses, según tengo dicho, y se retificaron en lo dicho, respondiéndome que yo era su padre espiritual y que a enseñarles el camino de su salvaçión vine, y para doctrinarlos y enseñarlos y salvarles sus almas por los medios que les enseñaba, y no para condenarles. Y, así, que no se había de haçer otra cosa más que lo que yo quisiera, siendo mayormente para bien de sus almas y cuerpos. Y esta repuesta me dieron delante de los dos atequíes, y que conosían lo bien que les estaba el dejar el juego de pelota. Y, así, que por ellos luego se dejara. Véase ahora si tendré rasón. Todo lo cual hise lo firmaran los dos atequies, así el de la igleçia como el del rey, para que en todo [583r] tiempo constase, pues ellos habían sido los que lo habían denunçiado, que éste es un tanto que concuerda con su original, que queda en mi poder.

Fecho en San Luis de Talimali, en veintitrés de setiembre, año de mil y seiscientos y setenta y seis. Diego Salvador. Holata Juan Mendoza. ${ }^{97}$ [Firmado:] Diego Salvador. Holata Juan Mendoza.

Yo, el capitán Martín Lorenzo de Labora, escribano de visita, doy fe y verdadero testimonio cómo los atequíes Diego Salvador y Juan de Mendoza reconosieron y vieron este cuaderno que dixeron ser el mesmo que contenía los atresos y superticiones del juego de pelota que la nación abalachina había estado jugando hasta el día que se sacó a luz este dicho cuaderno. Y para que conste doy el presente en el lugar de San Luis de Talimali, [583v] en veinte y seis días del mes de diziembre de mil y seiscientos y setenta y siete años.

[Firmado:] Martín Lorenzo de Labora, escribano de visita.

Recibido el 20 de octubre de 2015 Segunda versión el 11 de septiembre de 2016 Aceptado 19 de septiembre de 2016

\section{Referencias bibliográficas}

Bushnell, Amy T., «That Demonic Game: The Campaign to Stop Indian Pelota Playing in Spanish Florida, 1675-1684», The Americas, 35-1, 1978, 1-19.

Cervantes de Salazar, Francisco y Magallón, M. (ed.), Crónica de la Nueva Espa$\tilde{n} a$, Madrid, Atlas, 1971, 2 vols.

96 MS: en en.

97 El término holahta aparece en el diccionario de apalache con el significado de «cacique». Kimball, 1988, 392. 
Culin, Stewart, Games of the North American Indians, Lincoln, University of Nebraska Press, 1992 [1907], 2 vols.

DRAE, Diccionario de la Real Academia Española, 23. a edición, en línea en www.rae.es.

Ehrman, W. W., «The Timucua Indians of Sixteenth Century Florida», Florida Historical Quarterly, 18, 1940, 168-191.

García, Francisco, Vida y milagros de San Francisco Xavier, de la Compañía de Jesús, Madrid, Juan García Infanzón, 1672.

Hann, John H., Apalachee: The Land between the Rivers, Gainesville, University Press of Florida, 1988.

Hann, John H., «Father Juan de Paiva: Spanish Friar of Colonial Florida», en Henderson, Ann y Mormino, Gary (coords.), Spanish Pathways in Florida. Los caminos españoles en La Florida. 1492-1992, Sarasota, Pineapple Press, 1991, 140-167.

Hann, John H., «Political Leadership among the Natives of Spanish Florida», Florida Historical Quarterly, 71-2, 1992, 188-208.

Hann, John H. y McEwan, Bonnie G., The Apalachee Indians and Mission San Luis, Gainesville, University Press of Florida, 1998.

Hudson, Charles M., The Black Drink: A Native American Tea, Athens, University of Georgia Press, 2004.

Keyes, J. Gregory, «Myth and Social History in the Early Southeast», en Kwachka, Patricia B. (ed.), Perspectives on the Southeast: Linguistics, Archaeology, Ethnohistory, Athens, University of Georgia Press, 1994, 106-115.

Kimball, Geoffrey, «A Grammatical Sketch of Apalachee», International Journal of American Linguistics, 53-2, 1987, 136-174.

Kimball, Geoffrey, «An Apalachee Vocabulary», International Journal of American Linguistics, 54-4, 1988, 387-398.

Lankford, George E., Looking for Lost Lore: Studies in Folklore, Ethnology, and Iconography, Tuscaloosa, University of Alabama Press, 2008.

Lessing, Gotthold, Escritos filosóficos y teológicos, Barcelona, Anthropos, 1990.

Mason, John, The Ancient Civilizations of Peru, Baltimore, Penguin, 1957.

McEwan, Bonnie G., «Apalachee and Neighboring Groups», en Sturtevant, William C. (ed.), Handbook of North American Indians, Washington, Smithsonian, 2004, vol. XIV, 669-676.

Owen, Thomas McAdory, History of Alabama and Dictionary of Alabama Biography, Chicago, S. J. Clarke, 1921.

Perea Rodríguez, Óscar, «Juego de pelota», en Alvar, Carlos (dir.), Gran enciclopedia cervantina, Madrid, Castalia, 2015, vol. IX, 46-59.

Raglan, FitzRoy Richard Somerset, Lord, The Hero: A Study in Tradition, Myth and Drama, Mineola, Dover, 2003 [London, Methuen, 1936].

Scarry, John F., «Agency and Practice in Apalachee Province», en Scheiber, Laura L. y Mitchell, Mark D. (eds.), Across a Great Divide: Continuity and Change 
in Native North American Societies, 1400-1900, Tucson, University of Arizona Press, 2010, 23-41.

Schurhammer, Georg y Costelloe, M. Joseph (trad.), Francis Xavier, His Life, His Times, Roma, Jesuit Historical Institute, 1982, 4 vols.

Shields Jr., E. Thomson, «Negating Cultures, Saving Cultures: Franciscan Ethnographic Writings in Seventeenth-Century La Florida», en Herrera-Sobek, María y Sánchez Korrol, Virginia (eds.), Recovering the US Hispanic Literary Heritage, Houston, Arte Público Press, 2000, vol. III, 218-233.

Weisman, Brent R., Like Beads on a String. A Culture History of the Seminole Indians in North Peninsular Florida, Tuscaloosa, University of Alabama Press, 1989.

Wenhold, Lucy L., trad., «A 17th-century Letter of Gabriel Díaz Vara Calderón, Bishop of Cuba, Describing the Indians and Indian Missions of Florida», Smithsonian Miscellaneous Collections, 95-16, 1936, 19 pp.

Zubillaga, Félix (ed.), Cartas y escritos de san Francisco Javier, Madrid, Biblioteca de Autores Cristianos, 1979. 